\title{
Chromatographic analysis of honey ceramic artefacts
}

\author{
César Oliveira $^{1,2} \cdot$ Alfredo Araújo $^{1} \cdot$ Adriana Ribeiro $^{1} \cdot$ Cristina Delerue-Matos $^{1}$
}

\begin{abstract}
Honey was the main sweetening agent in the ancient world; it is mentioned in literary sources and archaeologically documented all over the Mediterranean basin. Its production extended throughout different parts of the Roman Empire, with important economic impacts on family economies, both as a foodstuff and as a commercial product. This paper focuses on the chromatographic analysis of Roman Iberian honeypots and ceramic beehives, identifying tracer characteristics from ancient honey in sherds from seven honeypots and three beehives. The obtained results present an important contribution to the knowledge of the local Roman Iberian economy, particularly relating to the production, transport and trade of honey in locally manufactured ceramic containers.
\end{abstract}

Keywords Archaeometry $\cdot$ Honeypots $\cdot$ Ceramic beehives $\cdot$ Molecular biomarkers $\cdot$ Gas chromatography coupled with mass spectrometry (GC/MS)

\section{Introduction}

Honey has been consumed since the very beginning of man's existence and was, for very long time, the only sweetener used by prehistoric individuals. The earliest records of the hunting and consumption of wild honey were located in Anatolia and are dated from the seventh millennium cal BC (Roffet-Salque et al. 2015). They were also found in the Iberian Peninsula rock paintings representing honey hunters climbing long rope ladders as they harvest sections of honeycomb, with a chronology not completely established but varying from the end of the Mesolithic until the end of the Neolithic (Bonet Rosado and Mata Parreño 1995, 1997; Crane 1983; Crane 1997; Crane and Graham 1985; Kritsky 2017).

The oldest traces of beehive products in the Mediterranean basin area are from the Iron Age. In fact, Rageot and coworkers reported for that period evidences of the exploitation of beehive products in Corsica (Rageot et al. 2016), while

César Oliveira

cesar.oliveira@graq.isep.ipp.pt

1 REQUIMTE/LAQV, Polytechnic of Porto, School of Engineering (ISEP), Porto, Portugal

2 Department of Heritage Studies, Porto University, Porto, Portugal
Regert and co-workers detected at the site of Grand Aunay (located near Le Mans, France) a sherd containing an organic visible residue composed by a mixture of beeswax with birch bark tar, probably used for coating (Regert et al. 2003).

Due to their numerous uses and high demand, humans have learned how to manage colonies of bees by providing them with hives to more easily access the honey.

The earliest representation of man-made hives dates back to an Egyptian temple from $2400 \mathrm{BC}$, where cylindrical hives are represented in a horizontal position (Crane 1983; Crane and Graham 1985; Jones et al. 1973; Kritsky 2017). The Egyptian beekeeping technology seems to have spread initially to Greece, where 2000-year-old horizontal clay hives have been excavated, and later to Rome (Crane 1983; Crane and Graham 1985). Honey production extended throughout different parts of the Empire, achieving a position of utmost importance in family economies, both as a foodstuff and as a commercial product (Bonet Rosado and Mata Parreño 1997; Crane 1983; Crane and Graham 1985; Crane 2013; Morais 2011).

Several Roman manuscripts describe the existence of horizontal hives and the skilful operations needed to care for the bees and collect honey with minimum disruption. In fact, Columella (De re rustica IX, VI) refers to these pottery beehives as getting sunburnt with the heat of the summer and frozen with the cold of the winter. The economic impacts of 
beekeeping were so evident to Roman legislators that Roman civil law considered bee's in a hive the property of the hive's owner and their unauthorized removal a theft condemned by law (Crane 2013).

In the ancient world, traditional beehives were made of different materials such as mud, wood, cork, clay or skeps and were mostly horizontally positioned. In addition, terracotta beehives were also popular, as they were durable, versatile (easy to couple two tubular beehives to construct a bigger hive) and easily transported. The most ancient apiary yet discovered is dating to the tenth to early ninth centuries BCE and is located at Tel Rehov, in the middle Jordan valley in northern Israel (Bloch et al. 2010; Kritsky 2017). These ceramic beehives were usually placed on the ground or on small platforms, installed individually or in stacks. The inner surfaces were striated to promote the adherence of the honeycombs (Bonet Rosado and Mata Parreño 1995), and the beehive ends were closed with caps manufactured with materials such as cork, wood, pottery or dried mud. The front cap had a small opening to allow the bees to fly in and out, while the back end was used for harvesting the beehive (Bloch et al. 2010). In that process, the apiarist could insert smoke through the end of the hive, forcing the bees to move to the front, inducing many of them to leave through the flight hole (Bonet Rosado and Mata Parreño 1995, 1997; Crane 1983; Crane and Graham 1985; Harissis 2014; Jones et al. 1973; Morais 2006). Ceramic hives are known in the Iberian Peninsula for pre-Roman times (Bonet Rosado and Mata Parreño 1997; Jardón Giner et al. 2009; Quixal Santos and Jardón Giner 2016).

The first evidence of containers used to transport honey dates back to the Bronze Age, as is pictured on Egyptian New Kingdom tombs dated to around $1500 \mathrm{BC}$ (Crane 2013) and on some Mycenaean Linear B tablets from approximately the same period (Hornblower et al. 2014; Palmer 1955; Weilhartner 2012). Some papyri of the Ptolemaic period refer to other types of containers used to transport honey (Bortolin 2008). The containers most frequently recovered by archaeologists are Roman and Byzantine, their identification as honeypots made possible due to inscriptions (graffiti and tituli picti) (Peña 2007). As well as selling honey in amphorae and in other medium-long distance transport containers, this product was also stored and sold at a local or regional level, in household instruments called instrumenta domestica (Persano 2016).

Although it is difficult to recognize the containers used to transport and preserve honey, there are some specific forms well documented in the Iberian Peninsula, in North Central Italy and throughout the Mediterranean basin, including Greek vases especially adapted for this purpose (Morais 2014; Persano 2016). These honeypots are characteristic containers due to a particularly pronounced shoulder (sometimes two) in the shape of a rim or "eyelash", generally placed about one third from the top of the vase or near their mouth (examples in Fig. 1). According to ethnographic parallels documented both in the Iberian Peninsula (several examples from Spain and Portugal are presented by Morais (2006) and Monserrat (2013)) and in Crete (Crane 1983), this particularity seems to occur for two practical reasons: (i) to create a water channel around the containers mouth and therefore prevent insects such as ants from reaching the product and (ii) to avoid leakage down the sides of the vessel (Monserrat 2013; Morais 2006; Persano 2016).

In this study, the organic residues present in ceramic fragments of honeypots (Fig. 1a-g) and beehives (Fig. 2a-c) were determined by gas chromatography coupled to mass spectrometry (additional data on the analysed materials is presented in Table 1). As the purpose of this study, we took into consideration that honey is a complex mixture of natural products, composed of about 200 different compounds, with high amounts of monosaccharides, such as fructose and glucose, and minor traces of disaccharides, trisaccharides and tetrasaccharides (Consonni et al. 2013); about $0.57 \%$ of organic acids such as gluconic, pyruvic, malic, citric, succinic and fumaric; minerals; vitamins; proteins; amino acids like proline (the dominant), arginine, tryptophan and cysteine; and lipids and phenolic acids such as gallic, $p$-coumaric, caffeic, ellagic, ferulic, chlorogenic, syringic, cinnamic, vanillic and $p$-hydroxybenzoic (Ciulu et al. 2016; Pereira 2008). One of its most characteristic compounds is 5hydroxymethylfurfural, formed by the dehydration of hexoses in acidic media (Fallico et al. 2008; Khalil et al. 2010; Kujawski and Namieśnik 2008). This compound is usually absent in fresh honey but its concentration tends to increase during storage even at low temperatures (Biluca et al. 2014).

The identification of honey residues was achieved by searching for biomarkers of honey. Archaeological biomarkers are "substances occurring in organic residues that provide information relating to human activity in the past" (Evershed 2008). However, while some chemical compounds offer a robust means of assigning their presence as components of organic residues, others do not present a univocal source. When such ambiguities exist, the true nature of organic residues can only be reached by the convergence of different biomarkers, providing robust evidences to support conclusions.

Despite present in aged honey, 5-hydroxymethylfurfural can also be produced during the initial stages of the Maillard reaction between amino compounds and reducing sugars from cooked foods processed at high temperature, as meat or milk (Tamanna and Mahmood 2015). Nevertheless, its detection reinforces the evidence of honey residues.

Besides beeswax tracers, biomarkers of honey have rarely been reported in archaeological contexts due to their high susceptibility to degradation under most environmental conditions. Therefore, their detection is usually indirectly made 


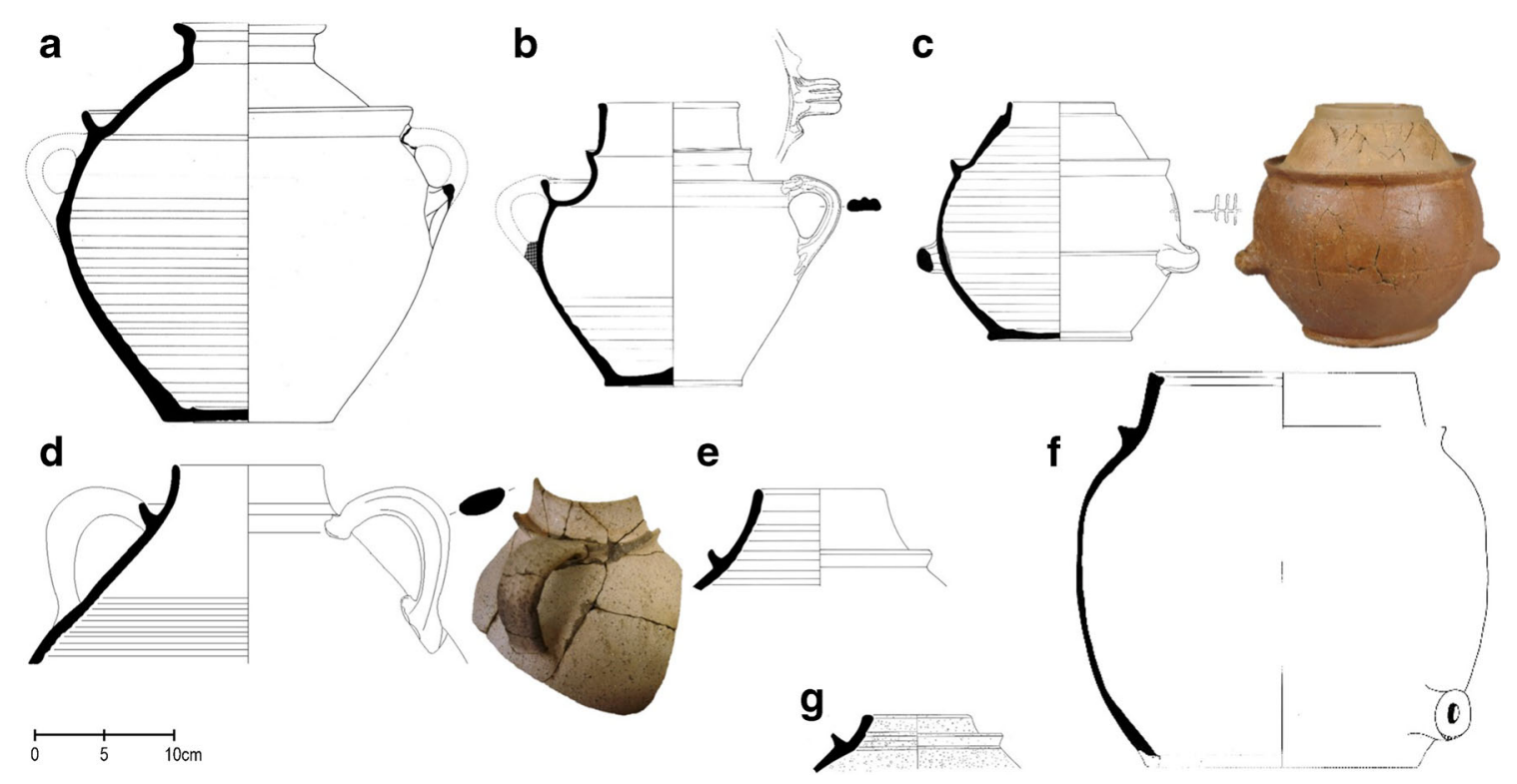

Fig. 1 Studied Portuguese honeypots. a-c Braga. d Chaves. e Matosinhos. f, g Conímbriga

by the presence of beeswax markers (Evershed et al. 2003; Evershed et al. 1997; Garnier et al. 2002; Heron et al. 1994; Needham and Evans 1987; Regert et al. 2001; Roffet-Salque et al. 2015).

In an attempt to better identify the chromatographic pattern of ancient honey, an experimental approach was used to simulate their natural degradation. Despite the interesting results obtained with the identification of honey chromatographic profile, we are aware that there are certain limitations on this experimental methodology as the past archaeological events cannot be fully replicated by experiments in the present (McGovern and Hall 2016).

The analytical methodology followed does not intend to identify traces of honey based on the detection of wax esters and long-chain alcohol characteristics of beeswax (Evershed et al. 2003; Evershed et al. 1997) but on the identification of carbohydrate compounds (Sanz et al. 2004) and other biomarkers of aged honey such as hydroxymethylfurfural, organic acids, amino acids and, eventually, biomass burning tracers (one of the important conclusions of this manuscript). Monosaccharides (glucose and fructose) and trisaccharide compounds were mostly identified as separated peaks, whereas the disaccharide fraction was detected as an extensive coelution of molecules (unresolved complex mixture) (de la Fuente et al. 2007; Kuhnert et al. 2013). In fact, disaccharides having glucose, galactose or mannose as their reducing moiety produce two well-resolved peaks with an area ratio of 3:1 to $10: 1$, those having fructose give two peaks with identical areas, while non-reducing saccharides as sucrose or trehaloses originate a single peak corresponding to an octakis-TMS derivative (Sanz et al. 2004). This profusion of different peaks per disaccharide resulted in compound co-elution.

\section{Materials and methods}

Measures were adopted to reduce manipulation and prevent sample contamination. Before use, all glassware was
Fig. 2 Studied ceramic beehives. a Braga. b, c Martinhal, Sagres
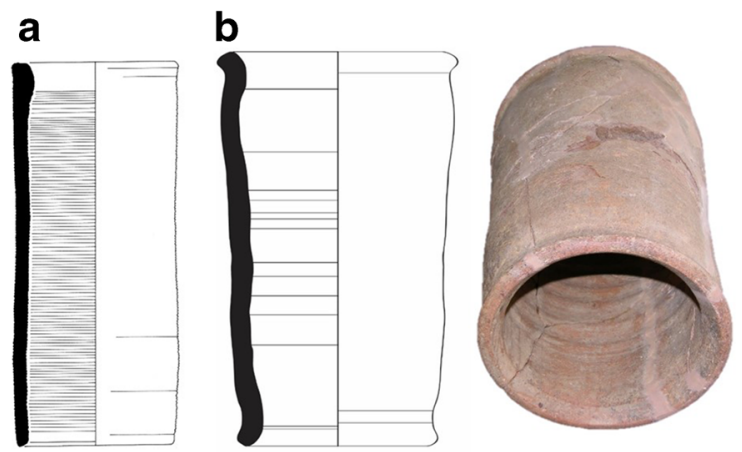

C
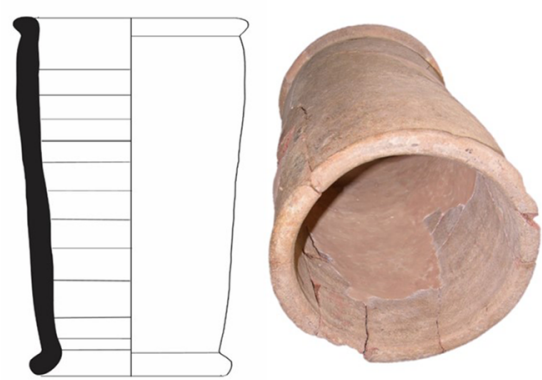

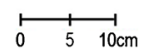


Table 1 Studied honeypots and ceramic beehives

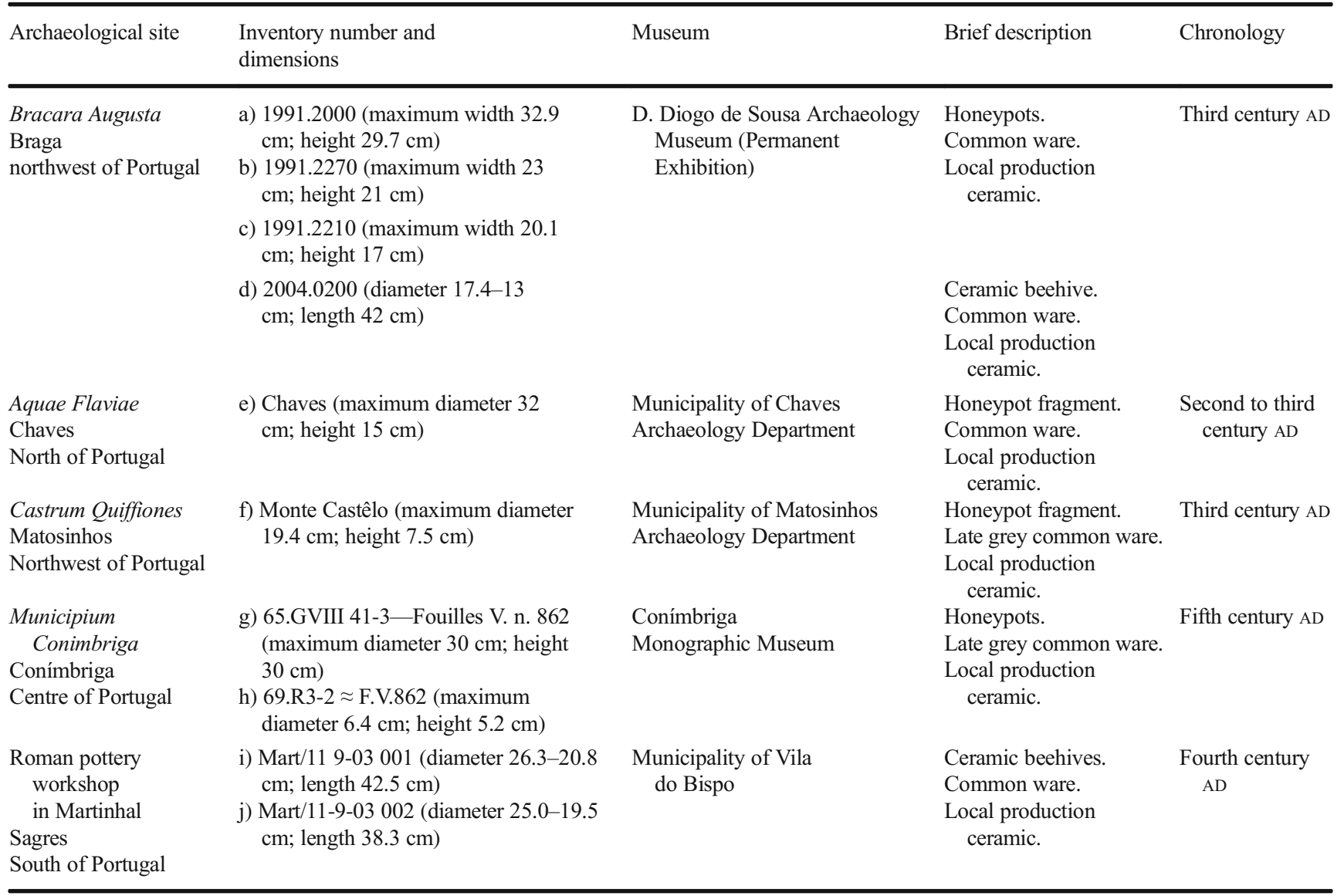

previously submerged for $24 \mathrm{~h}$ in chromosulfuric solution and rinsed with deionized water. New sterilized scalpels were used for each sample and the working surfaces of the laboratory benches were routinely decontaminated with ethanol $70 \%$. New sterilized gloves were used before the manipulation of sherds to prevent the samples' contamination with human fingerprints.

In a brief description of the adopted procedure, analysed sherds were mechanically cleaned with a scalpel before sampling to eliminate possible environmental contaminations (Kałużna-Czaplińska et al. 2016 present an interesting review on the different analytical procedures used on the study of organic residues in archaeological ceramic materials by GC-MS). After the first cleaning procedure, about $0.2 \mathrm{~g}$ of sherd was collected from each sample's surface and the materials crushed into fine powder on a pre-cleaned agate mortar to increase the contact area and improve the efficiency of extraction. The organic remains were extracted sequentially with dichloromethane and methanol in Soxhlet apparatus, filtered with $0.20-\mu \mathrm{m}$ PTFE syringe filters and concentrated on a rotary evaporator to about $2 \mathrm{~mL}$. The extraction periods were restricted to about $1 \mathrm{~h}$ per extract, being the maximum temperature limited to solvent boiling points, therefore minimizing thermal decomposition.

The concentrated extracts were transferred to vials, dried with a gentle nitrogen flow, dissolved in pyridine and derivatized with $\mathrm{N}, \mathrm{O}$-bis (trimethylsilyl) trifluoroacetamide (BSTFA): trimethylchlorosilane (TMCS) 99:1 for the analysis of the most polar compounds (Fox et al. 2000). No internal standards were used due to the heterogeneity of the samples, as the distribution of organic residues throughout the sample clay is not homogeneous, i.e. the porosity is not equally distributed along the sherd's structure and therefore, a quantification per gram of sherd is meaningless.

The chromatographic analyses were performed with an ion trap analyser VARIAN 4000 Performance device that was operated in full scan mode with the following experimental conditions: (a) column ZB-5MSi, $30 \mathrm{~m} \times 0.25 \mathrm{~mm} \times 0.25 \mu \mathrm{m}$ using helium as carrier gas with a constant flux of $1 \mathrm{~mL} \mathrm{~min}^{-1}$; (b) injection volume of $1 \mu \mathrm{L}$; (c) injector temperature of $250{ }^{\circ} \mathrm{C}$; (d) heating programme 60 to $150{ }^{\circ} \mathrm{C}\left(10 \mathrm{~min}^{-1}\right)$, 150 to $290{ }^{\circ} \mathrm{C}\left(5^{\circ} \mathrm{C} \min ^{-1}\right), 290{ }^{\circ} \mathrm{C}(27 \mathrm{~min})$; (e) ionisation mode, electronic impact at $70 \mathrm{eV}$; (f) interface and ionic source at $290{ }^{\circ} \mathrm{C}$; and (g) scanned masses from $\mathrm{m} / \mathrm{z} .50$ to 600. Compound identification was based on the GC/MS 
spectra libraries Wiley6 and NIST08, co-injection with authentic standards and analysis of fragmentation patterns (Oliveira et al. 2017).

This study included seven honeypots (Fig. 1) and three ceramic beehives (Fig. 2) from the Western Iberian Peninsula (Table 1). Samples were selected without any other criteria as being classified by archaeologists as honeypots or beehives from the roman period, recovered within the Portuguese national territory.

The composition of fresh honeys was also evaluated before and after accelerated processes of thermal degradation and dehydration, as an attempt to mimic the degradation of honey absorbed in ceramic vessels over archaeological timescales. This study was performed on two Portuguese monofloral honeys acquired to local beekeepers: honey from Campanula spp. flowers (from Castelo Branco region, centre of Portugal) and from Calluna vulgaris flowers (from Peneda-Gerês National Park, north of Portugal) and a multifloral honey (from unknown origin) bought in a local supermarket. The adopted procedure followed a similar protocol to the one conducted by Teodor and co-workers (Teodor et al. 2014) as an attempt to simulate the natural degradation and ageing of wine in ceramic vessels. In fact, a local potter from the city of Braga used local clays and roman similar pottery production techniques to model three reproductions of Fig. 1b honeypot (one example in Fig. 3). Each one of those modern ceramic vessels was filled for 2 days with a different honey type, decanting the excess honey after that time period. The containers with the walls impregnated with honey were then kept for 30 days in darkness at a constant temperature of $80{ }^{\circ} \mathrm{C}$ to simulate their degradation and dehydration though time. The vessels were subsequently fragmented into small pieces that followed the same analytical procedure as the sample sherds. This work sought to better identify biomarkers characteristic of the degraded honey. However, despite valuable, authors recognize that this methodology has limitations, as artificial ageing does not take into account the biological action in altering the sugar profile.

Sherds of two Roman open oil lamp specimens (Fig. 4 presents one of the analysed open oil lamps) recovered in the same archaeological context as the studied specimens from Bracara Augusta were also analysed to evaluate for possible post-depositional contamination with carbohydrates. As these two Roman open oil lamps were found in association with four of the analysed honeypot specimens (see Table 1), they were all subjected to the same environmental influence and therefore exposed to the same possible environmental contaminants. Therefore, the potential detection of carbohydrates in the sherds of these open oil lamp specimens would suggest a contamination of all the ceramic fragments recovered in that archaeologic context.

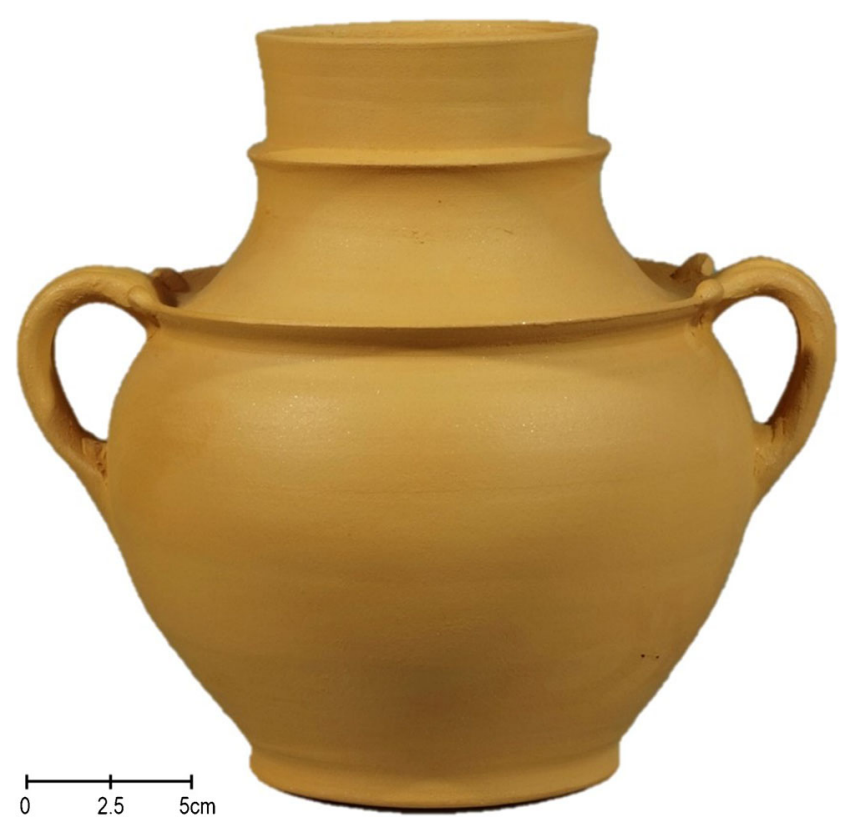

Fig. 3 One of the reproductions of Fig.1b honeypot used to mimic the degradation of honey absorbed in ceramic vessels over archaeological periods

\section{Main results and discussion}

Figures 5 and 6 present typical chromatograms of honeypots (Fig. 5a), beehives (Fig. 5b), an artificially aged honey (Fig. 5c) and an open oil lamp (Fig. 6).

Derivatized sugar GC profiles can be very hard to interpret as the presence of different tautomeric forms in solution gives rise to distinct derivatives for each tautomeric form of the sugar, producing a large number of chromatographic peaks per sugar, co-elution problems and complex chromatograms (Dhakal and Armitage 2013; Ruiz-Matute et al. 2011; Sanz et al. 2004). This behaviour frequently results in peak

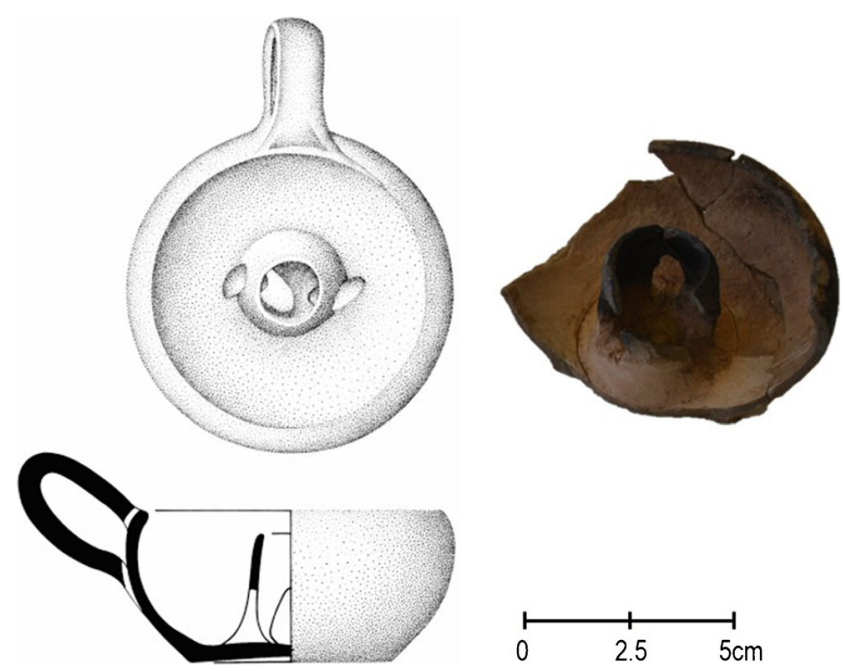

Fig. 4 Roman open oil lamp recovered during Bracara Augusta excavations at the same archaeological context as the analysed Bracara Augusta honeypots and ceramic beehive 


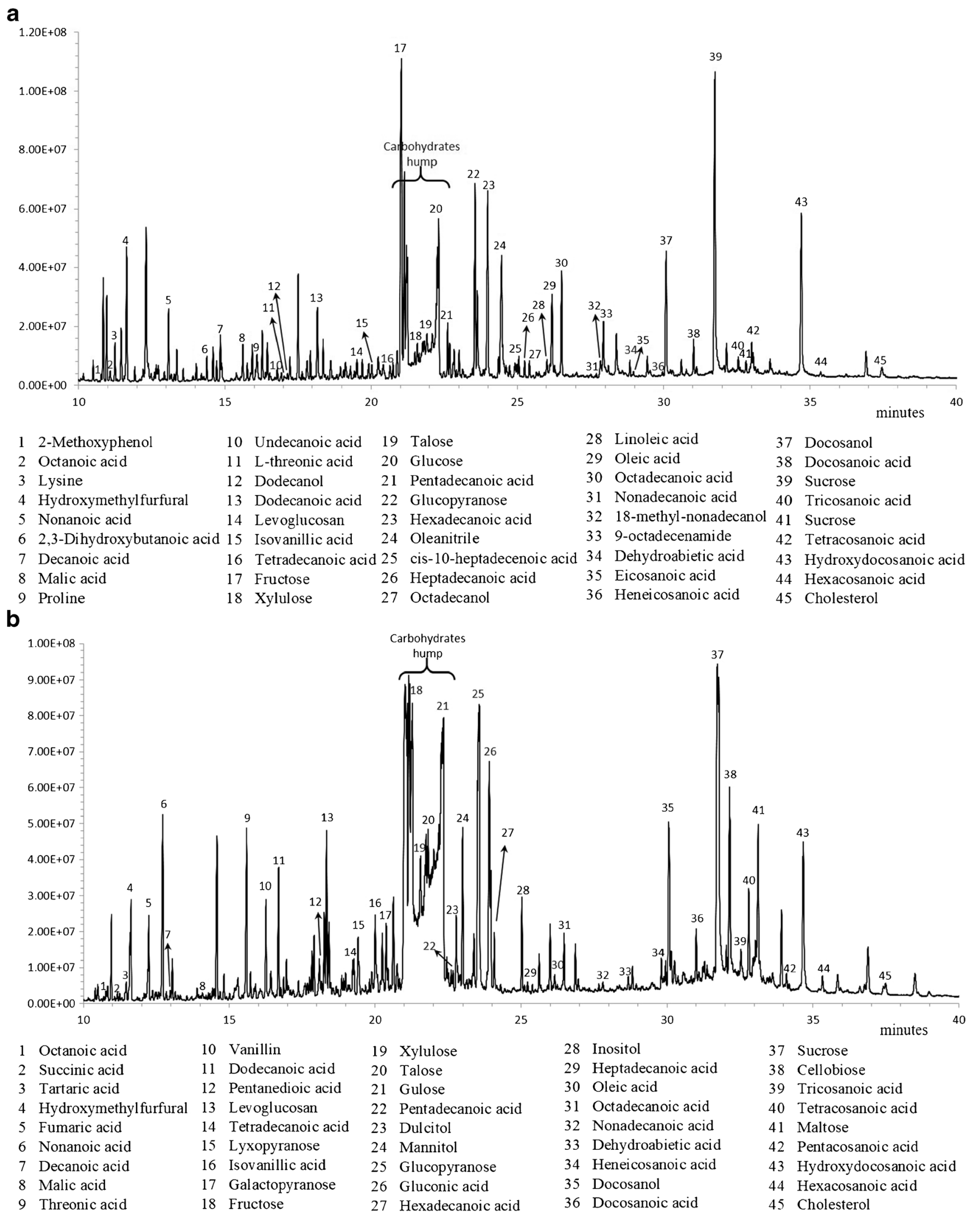

Fig. 5 Typical chromatograms. a Honeypots (sample 1991.2210; Fig. 1c). b Ceramic beehives (sample Mart/11 9-03 001; Fig. 2b). c Recent honey after accelerated ageing 


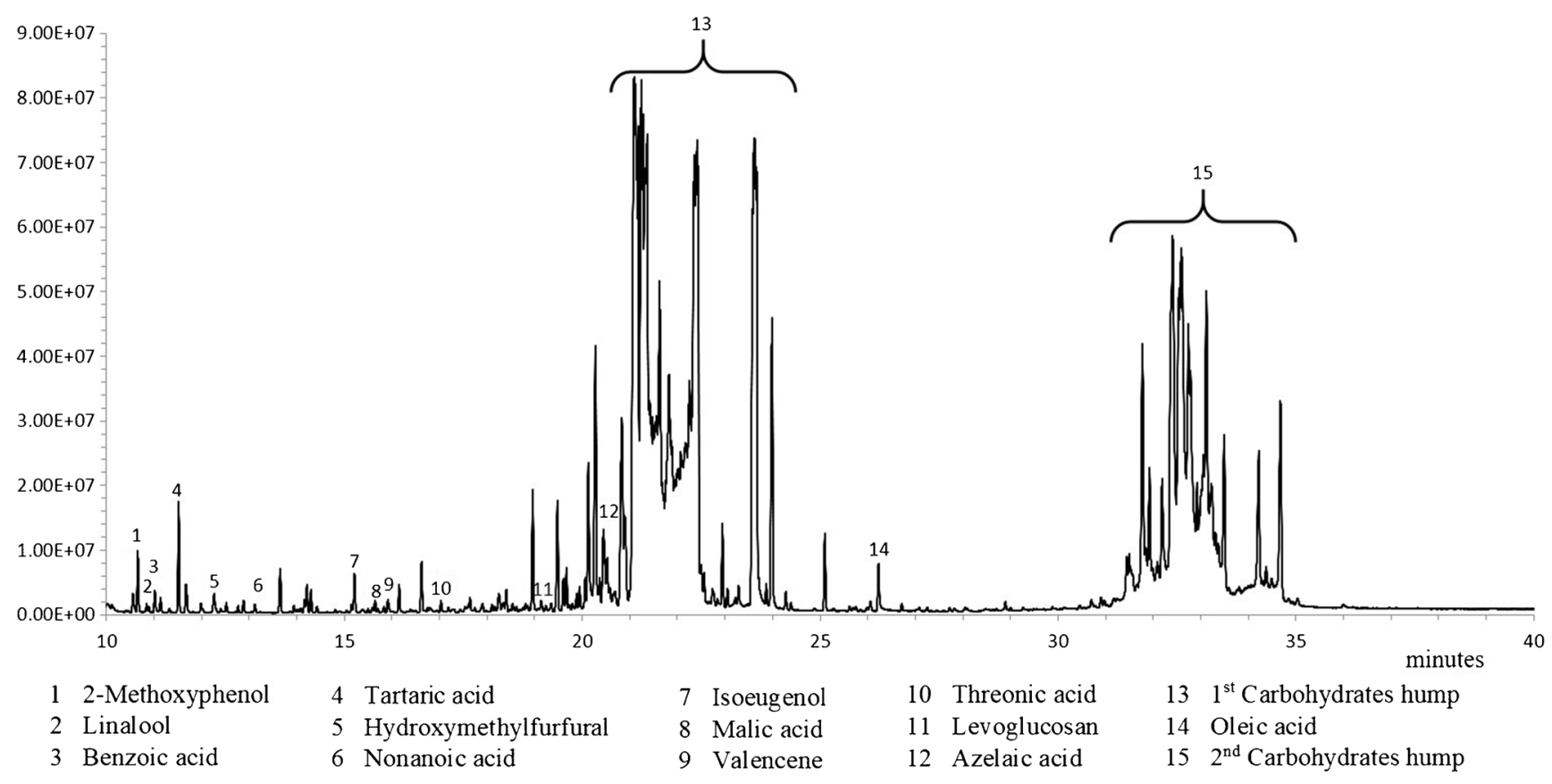

Fig. 5 (continued)

broadening, as seen in Fig. 5, that limits the identification of carbohydrates eluted with the same retention time (Sanz et al. 2004). In fact, all samples presented high amounts of carbohydrates, particularly monosaccharides such as fructose, glucose, galactopyranose, talose and xylulose, and lower intensities of disaccharides such as sucrose or lactose (Aliferis et al. 2010; de la Fuente et al. 2007; Feás et al. 2010; Kujawski and Namieśnik 2008). It is important to highlight the hump
(Kuhnert et al. 2013) detected from 21.50 to $22.40 \mathrm{~min}$ that was found in all the analysed honeypots, ceramic beehives and artificially aged honey samples, corresponding to an unresolved mixture of carbohydrates that co-elute (Fig. 5a-c). In fact, the average mass spectra ( 21.50 to $22.40 \mathrm{~min}$ ) of the analysed honeypots and ceramic beehive humps (Fig. 7a) are almost overlapping with the average mass spectra acquired at identical time period for the artificially aged honey samples

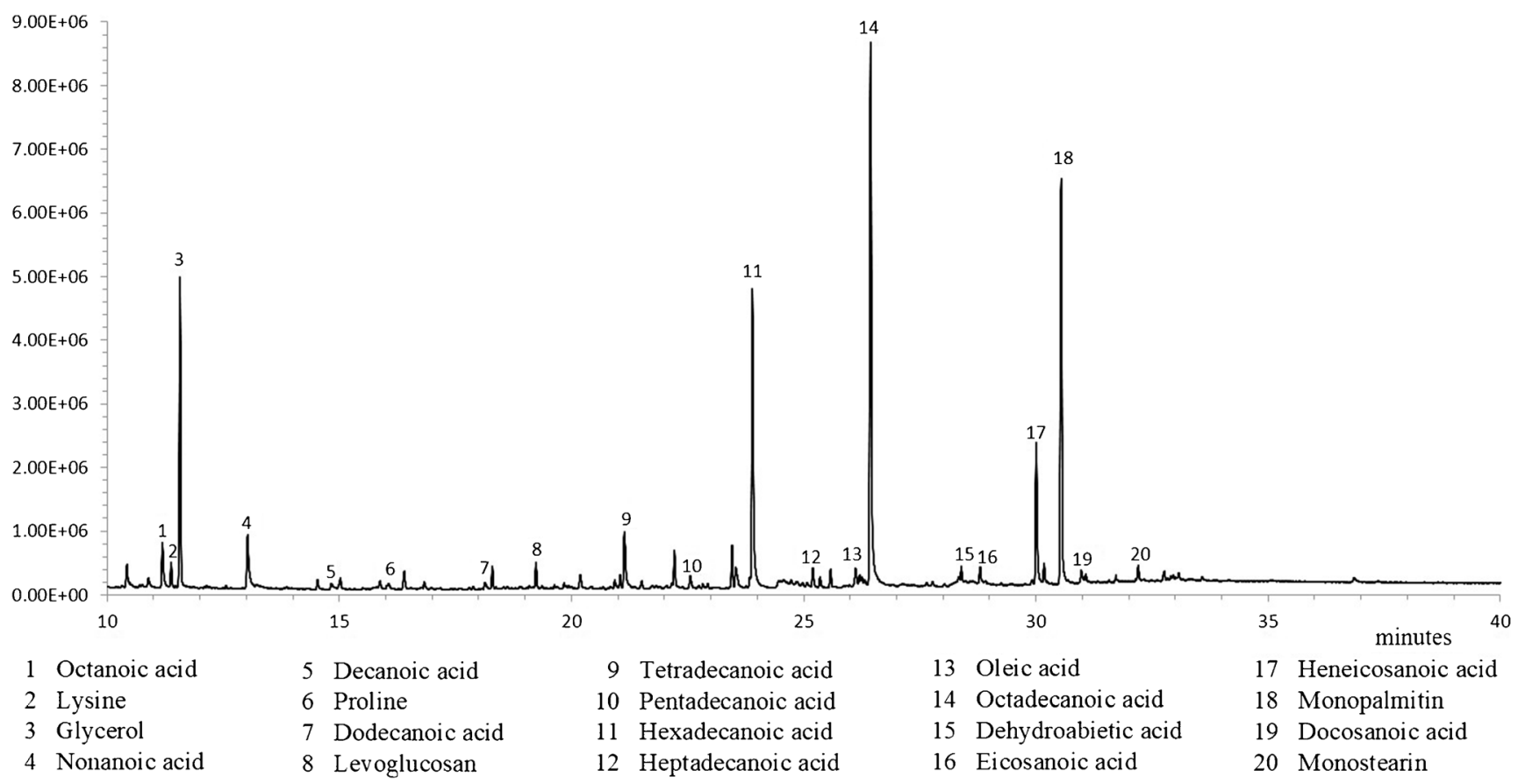

Fig. 6 Typical chromatogram of an open oil lamp sherd recovered in the same archaeological context as the studied specimens from Bracara Augusta 
Fig. 7 Comparison of mass spectra (average spectra acquired from 21.50 to $22.40 \mathrm{~min}$ ). a Honeypot (sample 1991.2210; Fig. 1c). b Recent honey after accelerated ageing. An identical pattern was obtained on all the analysed honeypots and ceramic beehive chromatograms a

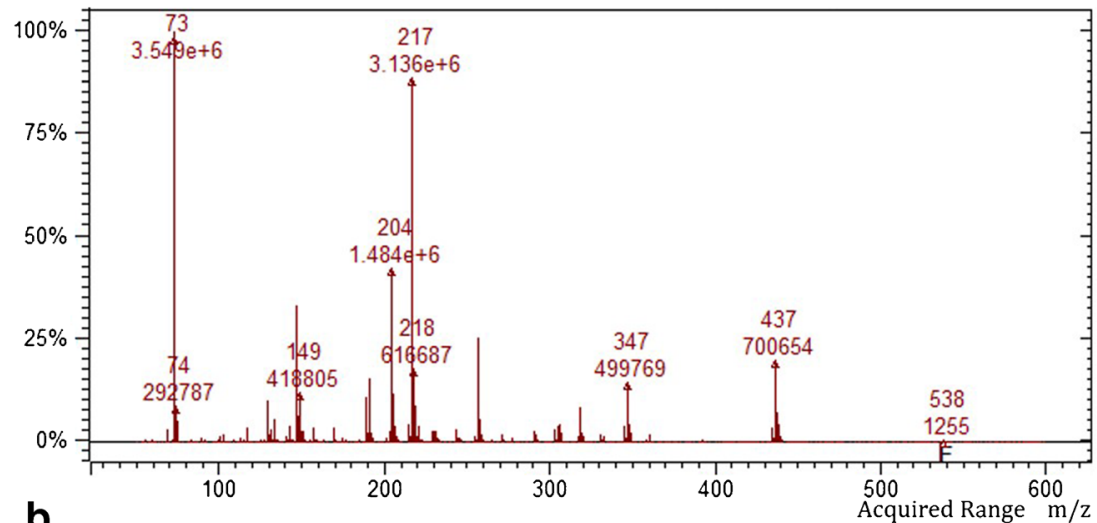

$$
\text { b }
$$

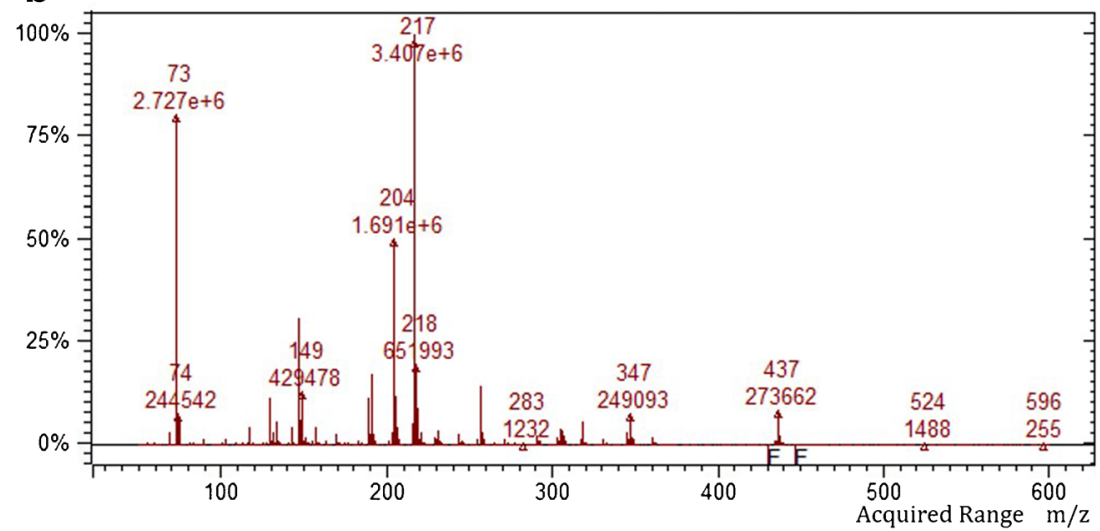

(Fig. 7b). This point strongly suggests a similar chemical composition among them and supports the hypothesis of the presence of honey residues on the ancient sherds.

Carbohydrates are unlikely to survive in buried archaeological material, as they are water soluble and therefore easily leached or assimilated by microorganisms. Therefore, their detection in the analysed sherds has to be evaluated with caution to prevent for sample contamination. To better explain their occurrence in the analysed sherds, fragments of two other ceramic objects - two Roman open oil lamp specimens - recovered in the same archaeological context as the studied specimens from Bracara Augusta were also studied to evaluate for possible post-depositional contamination with carbohydrates (one example is presented in Fig. 6). Both chromatograms revealed the presence of palmitic, stearic and oleic acids (Kimpe et al. 2001), together with levoglucosan (compounds characteristic of the fuel used) (Heron et al. 2016), the absence of any carbohydrate hump nor any remarkable carbohydrate peak and a lack of cholesterol which would indicate human contamination. These data are extremely important to more comfortably assign the carbohydrate hump to the vessels content and not to any external contamination.

This possibility is also supported by the detection of hydroxymethylfurfural (HMF) in all chromatograms from honeypots, ceramic beehives and recent honey after accelerated ageing (acquired mass spectrum is presented in Fig. 8a).
In fact, HMF is a compound naturally synthetized by the cyclization of hexoses such as glucose, mannose or galactose and achieved by the chemical and physical phenomenon of dehydration (Chua et al. 2014; de la Fuente et al. 2007; Senila et al. 2012; Teixidó et al. 2006; Zappalà et al. 2005). The detection of HMF is one of the most used indexes to detect low-quality honey, its overheating and/or its ageing (Chernetsova et al. 2011; Fallico et al. 2008; Zappalà et al. 2005).

Some of the studied samples revealed the presence of proline and lysine. Proteins and amino acids are important components of honey and can present both animal and vegetal origin. In fact, amino acids represent about $1 \%$ of honey, with proline the most abundant amino acid (Baldi Coronel and Baldi Coronel 2001), signifying more than half of the total amino acids present, together with small amounts of lysine, tyrosine and phenylalanine in a total of 26 different amino acids (Hermosín et al. 2003). Proline has its major source in the salivary secretions of honeybees during their conversion of nectar into honey (da Silva et al. 2016; Hermosín et al. 2003; Kaškoniene and Venskutonis 2010). In fact, the amount of proline in honey has been suggested as an indicator of honey maturity (da Silva et al. 2016; von der Ohe et al. 1991).

Organic acids represent less than $0.5 \%$ of honey's constituents, being the honey's total acidity used as an indicator of its 
Fig. 8 Acquired mass spectra (TMS derivatives). a Hydroxymethylfurfural. b $\omega$ Hydroxydocosanoic acid. c Dehydroabietic acid a

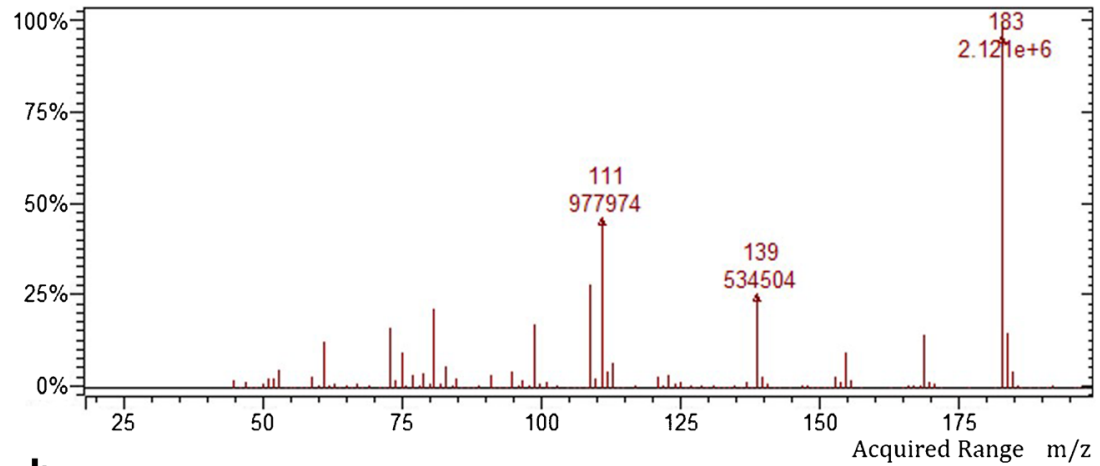

b

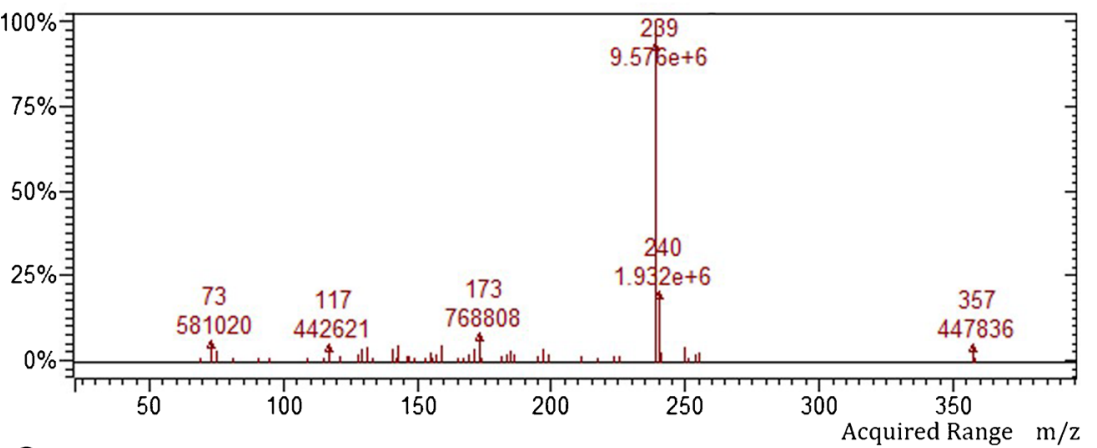

C

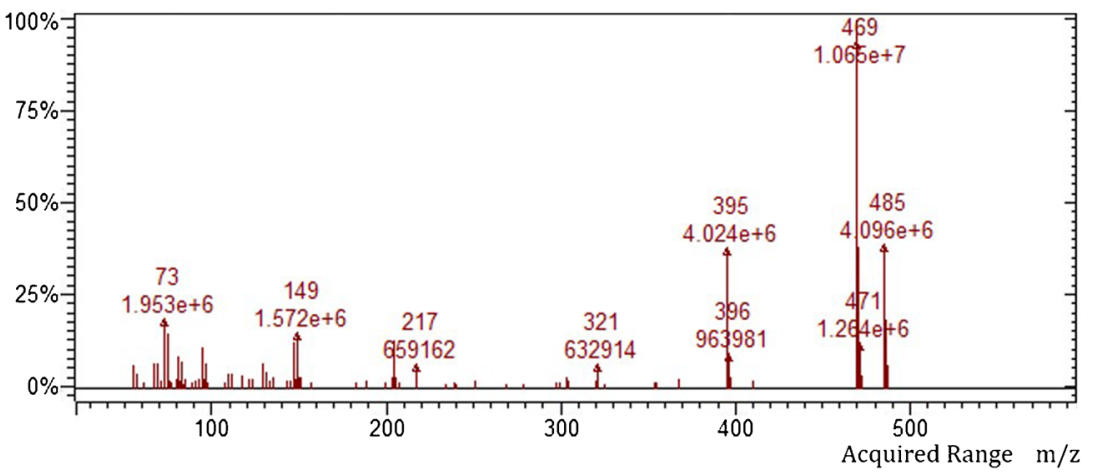

deterioration due to storage, ageing or even to measure its purity and authenticity (Suarez-Luque et al. 2002). The analysed samples revealed small amounts of minority organic acids such as succinic, gluconic, threonic, malic and tartaric acids (Nozal et al. 2003), these being organic acids compatible with the presence of honey residues, among other matrices (Hermosín et al. 2003).

One of the novelties of this study was the detection of levoglucosan (LG) and dehydroabietic acid (DHA). In fact, $L G$ is a well-known fire biomarker for the burning of cellulosic materials like woods or plants (Caseiro and Oliveira 2012; Fabbri et al. 2009; Fraser and Lakshmanan 2000; Gao et al. 2016; Kirchgeorg et al. 2014; Kuo et al. 2008; Simoneit 2002; Simoneit et al. 1999), while DHA is a diterpenic compound produced by the heat of abietic acid throughout a dehydrogenation process, and one of the main components in resins of Pinaceae origin
(Jerković et al. 2011). Both LG and DHA (Fig. 8b presents the DHA experimental mass spectrum) were ubiquitously present through all the analysed honeypots and beehive sherds but not in the artificially aged honey samples, supporting the hypothesis of contamination by smoke, probably with the combustion of biomass products (wood or foliage) from trees of the Pinaceae family (Jordan et al. 2006). In our opinion, this fact could suggest two possible and/or cumulative sources:

1. Smoke released during the process of harvesting to calm the bees and allow a more secure access to honey (Crane 1983; Crane 1997; Harissis 2014; Jones et al. 1973). With this procedure, honey would be adulterated with smoke residues.

2. Smoke released during the coating of the vessels for waterproofing purposes. 
The possible contamination of honey with traces of biomass burning can be easily understood by better understanding the process of harvesting. In fact, it is still common nowadays to use a fumigation device to calm the bees and allow safer access to the honey. However, strong smoking is unnecessary in modern hives with removable combs, and therefore modern beekeepers are able to use a minimum of smoking (Jones et al. 1973). In antiquity, the fumigation was performed by burning vegetal material such as wood and foliage (Bonet Rosado and Mata Parreño 1997; Crane 1992; Harissis 2014; Mason and Mason 1984), resulting in the release of biomass burning tracers that would impregnate the honey (Caseiro and Oliveira 2012; Oliveira et al. 2014; Simoneit 2002; Simoneit et al. 1999).

The additional presence of intense $\omega$-hydroxydocosanoic acid peaks (acquired mass spectrum presented in Fig. 8c) on both honeypots and ceramic beehive chromatograms (Fig. 5a, b) does support a diagnosis of honey ceramic containers. In fact, beeswax is rich in $\omega$-hydroxy acids, particularly those with an even number of carbons ranging from $\mathrm{C} 12$ to $\mathrm{C} 32$ (Bonaduce and Colombini 2004; Bonaduce et al. 2016; Colombini et al. 2009; Evershed et al. 1997; Regert et al. 2001; Tulloch 1971).

Another curious marker was cholesterol, widely considered a biomarker for the presence of fat residues. In fact, some of the studied fragments exhibited traces of cholesterol, but no squalene was detected. The two compounds are found on human fingerprints, and although cholesterol subsists over archaeological time, squalene rapidly degrades (Heron et al. 2010). Therefore, the absence of squalene indicates cholesterol as a sample component and not a result of more recent handling. The possible source of cholesterol was investigated, analysing artificially aged recent honeys (a typical chromatogram is presented in Fig. 5c). However, the data revealed the absence of cholesterol even after their artificial ageing. Major developments were obtained by complementing the chemical study with ethnographical considerations. In fact, modern and ancient beehives present very different shapes, as the ancient hives are long tubular containers while the modern hives use boxes of wooden mobile frames (for combs) equally spaced (Crane 1997). With that system, harvesting is possible without affecting the queen and brood. The tubular shape of ancient hives required pressing the honeycombs from their ceramic container, sometimes combining the process with the use of boiling water as recommended by Pliny (HN 21.83-84) and Columella (Rust. 9.16.1), particularly in the presence of large amounts of wax that needed to be separated from honey. By using that method, some bees and larvae still inside their honeycombs could be crushed together with honey and beeswax and contaminate honey with traces of cholesterol (Ferreira-Caliman et al. 2012). In fact, following Columella's description, the crushed beeswax and honey material were put inside a large container that had to be partially filled with water. The water should be brought to boil and the mixture strained through grass to remove particles such as parts of bees, before being boiled again (Kritsky 2015). It is important to stress that bees use sterols in a variety of key metabolic pathways, as the production of their moulting hormones (Joshi and Agarwal 1977; Svoboda et al. 1986; Vanderplanck et al. 2011). Therefore, in the absence of any other explanation, one plausible hypothesis to justify the existence of cholesterol in ancient honey is the presence of parts of bees that would contaminate the honey (Ferreira-Caliman et al. 2012; Ikekawa et al. 1993; Joshi and Agarwal 1977).

\section{Final remarks}

The chromatographic analysis using a GC/MS technique performed on Iberian Roman honeypots and ceramic beehives confirmed their use for identical purpose as their ethnographical parallels. The presence of cholesterol in ancient beehives was justified using complementary data from ethnographic parallels.

To our best knowledge, this is the first work where chromatographic techniques where applied to the study of Roman Iberian ceramic beehives and honeypots. Conducting chemical analyses on these container sherds is of the utmost importance to archaeology as it provides scientific evidence that corroborates classical sources, while also providing firsthand information on the function of these ceramic artefacts. In fact, one of the recurrent archaeological problems has been to accurately assess what products were used, transported and traded in certain ceramic vessels, given that the absence of chemical evidence forces archaeologists to conjecture based on stereotypes created by their ceramic typology classifications according to their physical characteristics.

The obtained results validate archaeologists' suspicions about the function of containers with recent ethnographic parallels, also revealing the economic value of honey and their use as a sweetener in the westernmost part of the Roman world.

Acknowledgements D. Diogo de Sousa Archaeology Museum is acknowledged by providing information on the archaeological context and chronology of the studied materials.

Funding information This work received financial support from the European Regional Development Fund (ERDF) through COMPETEOperational Competitiveness Programme and national funds provided by FCT-Foundation for Science and Technology under the project UID/ QUI/50006/2013. César Oliveira acknowledges Instituto de Ciências e Tecnologias Agrárias e Agro-Alimentares-Porto (ICETA) for his contract under project NORTE-01-0145-FEDER-000011. This work was partially financed by PTDC/EPH-ARQ/5204/2012 research project (Portuguese Science Foundation). 


\section{References}

Aliferis KA, Tarantilis PA, Harizanis PC, Alissandrakis E (2010) Botanical discrimination and classification of honey samples applying gas chromatography/mass spectrometry fingerprinting of headspace volatile compounds. Food Chem 121(3):856-862. https://doi. org/10.1016/j.foodchem.2009.12.098

Baldi Coronel GD, Baldi Coronel BM (2001) Honey detection, through proline analysis in hard honey caramels. Apiacta 2 88(4):391-396

Biluca FC, Della Betta F, de Oliveira GP, Pereira LM, Gonzaga LV, Costa ACO, Fett R (2014) 5-HMF and carbohydrates content in stingless bee honey by $\mathrm{CE}$ before and after thermal treatment. Food Chem 159:244-249. https://doi.org/10.1016/j.foodchem.2014.03.016

Bloch G, Francoy TM, Wachtel I, Panitz-Cohen N, Fuchs S, Mazar A (2010) Industrial apiculture in the Jordan valley during biblical times with Anatolian honeybees. Proc Natl Acad Sci 107(25):1124011244

Bonaduce I, Colombini MP (2004) Characterisation of beeswax in works of art by gas chromatography-mass spectrometry and pyrolysis-gas chromatography-mass spectrometry procedures. J Chromatogr A 1028(2):297-306. https://doi.org/10.1016/j.chroma.2003.11.086

Bonaduce I, Ribechini E, Modugno F, Colombini MP (2016) Analytical approaches based on gas chromatography mass spectrometry $(\mathrm{GC} /$ MS) to study organic materials in artworks and archaeological objects. Top Curr Chem 374(1):6. https://doi.org/10.1007/s41061-0150007-x

Bonet Rosado H, Mata Parreño C (1995) Testimonios de apicultura en epoca iberica. Verdolay 7:277-285

Bonet Rosado H, Mata Parreño C (1997) The archaeology of beekeeping in Pre-Roman Iberia. J Mediterr Archaeol 10(1):33-47

Bortolin R (2008) Archeologia del miele. SAP, Mantova

Caseiro A, Oliveira C (2012) Variations in wood burning organic marker concentrations in the atmospheres of four European cities. J Environ Monit 14(8):2261-2269. https://doi.org/10.1039/c2em10849f

Chernetsova ES, Revelsky IA, Morlock GE (2011) Fast quantitation of 5 hydroxymethylfurfural in honey using planar chromatography. Anal Bioanal Chem 401(1):325-332. https://doi.org/10.1007/s00216011-5081-5

Chua L, Adnan N, Abdul-Rahaman N, Sarmidi M (2014) Effect of thermal treatment on the biochemical composition of tropical honey samples. Int Food Res J 21(2):773-778

Ciulu M, Spano N, Pilo MI, Sanna G (2016) Recent advances in the analysis of phenolic compounds in unifloral honeys. Molecules 21(4):451-482. https://doi.org/10.3390/molecules21040451

Colombini MP, Modugno F, Ribechini E, (2009) GC/MS in the characterization of lipids. In: Organic mass spectrometry in art and archaeology. John Wiley \& Sons, Ltd., Chichester, pp 189-213

Consonni R, Cagliani LR, Cogliati C (2013) Geographical discrimination of honeys by saccharides analysis. Food Control 32(2):543-548. https://doi.org/10.1016/j.foodcont.2013.01.038

Crane E (1983) The archaeology of beekeeping. Gerald Duckworth \& Co Ltd., London

Crane E (1992) The world's beekeeping-past and present. in: Graham JM (ed) The hive and the honey bee. Datant \& Sons, Hamilton, pp 1-22

Crane E (1997) Look at it this way. Outlook Agric 26(1):3-5. https://doi. org/10.1177/003072709702600102

Crane EE (2013) The world history of beekeeping and honey hunting. Routledge, Abingdon

Crane E, Graham AJ (1985) Bee hives of the ancient world. 1. Bee World 66(1):23-41. https://doi.org/10.1080/0005772X.1985.11098818

da Silva PM, Gauche C, Gonzaga LV, Costa ACO, Fett R (2016) Honey: chemical composition, stability and authenticity. Food Chem 196: 309-323. https://doi.org/10.1016/j.foodchem.2015.09.051 de la Fuente E, Sanz ML, Martínez-Castro I, Sanz J, Ruiz-Matute AI (2007) Volatile and carbohydrate composition of rare unifloral honeys from Spain. Food Chem 105(1):84-93. https://doi.org/10. 1016/j.foodchem.2007.03.039

Dhakal B, and Armitage RA (2013) GC-MS characterization of carbohydrates in an archaeological use residue: a case study from the Coahuila Desert, in Archaeological Chemistry VIII, 157-170, ACS symposium series, 1147, American Chemical Society

Evershed RP (2008) Organic residue analysis in archaeology: the archaeological biomarker revolution. Archaeometry 50(6):895-924. https://doi.org/10.1111/j.1475-4754.2008.00446.x

Evershed RP, Vaughan SJ, Dudd SN, Soles JS (1997) Fuel for thought? Beeswax in lamps and conical cups from Late Minoan Crete. Antiquity 71(274):979-985. https://doi.org/10.1017/ S0003598X00085860

Evershed RP, Dudd SN, Anderson-Stojanovic VR, Gebhard ER (2003) New chemical evidence for the use of combed ware pottery vessels as beehives in ancient Greece. J Archaeol Sci 30(1):1-12. https:// doi.org/10.1006/jasc.2001.0827

Fabbri D, Torri C, Simoneit BRT, Marynowski L, Rushdi AI, Fabiańska MJ (2009) Levoglucosan and other cellulose and lignin markers in emissions from burning of Miocene lignites. Atmos Environ 43(14): 2286-2295. https://doi.org/10.1016/j.atmosenv.2009.01.030

Fallico B, Arena E, Zappala M (2008) Degradation of 5hydroxymethylfurfural in honey. J Food Sci 73(9):C625-C631. https://doi.org/10.1111/j.1750-3841.2008.00946.x

Feás X, Pires J, Iglesias A, Estevinho ML (2010) Characterization of artisanal honey produced on the northwest of Portugal by melissopalynological and physico-chemical data. Food Chem Toxicol 48(12):3462-3470. https://doi.org/10.1016/j.fct.2010.09. 024

Ferreira-Caliman MJ, da Silva CI, Mateus S, Zucchi R, do Nascimento FS (2012) Neutral sterols of cephalic glands of stingless bees and their correlation with sterols from pollen. Psyche, 2012:1-7. https:// doi.org/10.1155/2012/982802

Fox A, Kozar MP, Steinberg PA (2000) Carbohydrates | gas chromatography and gas chromatography-mass spectrometry. In: Encyclopedia of separation science. I. D. A2-Wilson, ed., Academic Press, Oxford, pp 2211-2223. https://doi.org/10.1016/ B0-12-226770-2/01021-8

Fraser MP, Lakshmanan K (2000) Using levoglucosan as a molecular marker for the long-range transport of biomass combustion aerosols. Environ Sci Technol 34(21):4560-4564. https://doi.org/10.1021/ es9912291

Gao X, Norwood M, Frederick C, McKee A, Masiello CA, Louchouarn P (2016) Organic geochemical approaches to identifying formation processes for middens and charcoal-rich features. Org Geochem 94:1-11. https://doi.org/10.1016/j.orggeochem.2016.01.007

Garnier N, Cren-Olivé C, Rolando C, Regert M (2002) Characterization of archaeological beeswax by electron ionization and electrospray ionization mass spectrometry. Anal Chem 74(19):4868-4877. https://doi.org/10.1021/ac025637a

Harissis HV (2014) Beekeeping in prehistoric Greece. In: International symposium: beekeeping in the Mediterranean from antiquity to the present. Syros, pp 14-35

Hermosín I, Chicón RM, Dolores Cabezudo M (2003) Free amino acid composition and botanical origin of honey. Food Chem 83(2):263268

Heron C, Nemcek N, Bonfield K, Dixon D, Ottaway B (1994) The chemistry of Neolithic beeswax. Naturwissenschaften 81(6):266-269. https://doi.org/10.1007/BF01131579

Heron C, Nilsen G, Stern B, Craig O, Nordby C (2010) Application of lipid biomarker analysis to evaluate the function of 'slab-lined pits' in Arctic Norway. J Archaeol Sci 37(9):2188-2197. https://doi.org/ 10.1016/j.jas.2010.03.016 
Heron C, Shoda S, Breu Barcons A, Czebreszuk J, Eley Y, Gorton M, Kirleis W, Kneisel J, Lucquin A, Müller J, Nishida Y, Son J-h, Craig OE (2016) First molecular and isotopic evidence of millet processing in prehistoric pottery vessels. Sci Rep 6(1):38767. https://doi. org/10.1038/srep38767

Hornblower S, Spawforth A, and Eidinow E (2014) The Oxford companion to classical civilization, Oxford Companions. https://doi.org/10. 1093/acref/9780198706779.001.0001

Ikekawa N, Morisaki M, Fujimoto Y (1993) Sterol metabolism in insects: dealkylation of phytosterol to cholesterol. Acc Chem Res 26(4): 139-146. https://doi.org/10.1021/ar00028a002

Jardón Giner P, Quixal Santos D, Mata Parreño C, Ntinou M, and Pascual Berlanga G (2009) La Fonteta Ràquia: une installation apicole du IIIe siècle av. J.-C. dans la péninsule Ibérique, Lunula, XVII, pp 193-200

Jerković I, Marijanović Z, Gugić M, Roje M (2011) Chemical profile of the organic residue from ancient amphora found in the Adriatic Sea determined by direct GC and GC-MS analysis. Molecules 16(9): 7936-7948. https://doi.org/10.3390/molecules16097936

Jones JE, Graham AJ, Sackett LH, Geroulanos MI (1973) An Attic country house below the cave of Pan at Vari. Annual British School Athens 68:355-452. https://doi.org/10.1017/S0068245400004524

Jordan TB, Seen AJ, Jacobsen GE (2006) Levoglucosan as an atmospheric tracer for woodsmoke. Atmos Environ 40(27):5316-5321. https:// doi.org/10.1016/j.atmosenv.2006.03.023

Joshi M, Agarwal HC (1977) Site of cholesterol absorption in some insects. J Insect Physiol 23(3):403-404. https://doi.org/10.1016/ 0022-1910(77)90280-3

Kałużna-Czaplińska J, Rosiak A, Kwapińska M, Kwapiński W (2016) Different analytical procedures for the study of organic residues in archeological ceramic samples with the use of gas chromatographymass spectrometry. Crit Rev Anal Chem 46(1):67-81. https://doi. org/10.1080/10408347.2015.1008130

Kaškonienè V, Venskutonis PR (2010) Floral markers in honey of various botanical and geographic origins: a review. Compr Rev Food Sci Food Saf 9(6):620-634. https://doi.org/10.1111/j.1541-4337.2010. 00130.x

Khalil M, Sulaiman S, Gan S (2010) High 5-hydroxymethylfurfural concentrations are found in Malaysian honey samples stored for more than one year. Food Chem Toxicol 48(8):2388-2392. https://doi. org/10.1016/j.fct.2010.05.076

Kimpe K, Jacobs PA, Waelkens M (2001) Analysis of oil used in late Roman oil lamps with different mass spectrometric techniques revealed the presence of predominantly olive oil together with traces of animal fat. J Chromatogr A 937(1-2):87-95. https://doi.org/10. 1016/S0021-9673(01)01304-8

Kirchgeorg T, Schüpbach S, Kehrwald N, McWethy DB, Barbante C (2014) Method for the determination of specific molecular markers of biomass burning in lake sediments. Org Geochem 71:1-6. https:// doi.org/10.1016/j.orggeochem.2014.02.014

Kritsky G (2015) The tears of re: beekeeping in ancient Egypt. Oxford University Press, Oxford

Kritsky G (2017) Beekeeping from antiquity through the middle ages. Annu Rev Entomol 62(1):249-264. https://doi.org/10.1146/ annurev-ento-031616-035115

Kuhnert N, Dairpoosh F, Yassin G, Golon A, Jaiswal R (2013) What is under the hump? Mass spectrometry based analysis of complex mixtures in processed food-lessons from the characterisation of black tea thearubigins, coffee melanoidines and caramel. Food Funct 4(8):1130-1147. https://doi.org/10.1039/c3fo30385c

Kujawski MW, Namieśnik J (2008) Challenges in preparing honey samples for chromatographic determination of contaminants and trace residues. TrAC Trends Anal Chem 27(9):785-793. https://doi.org/ 10.1016/j.trac.2008.07.004

Kuo L-J, Herbert BE, Louchouarn P (2008) Can levoglucosan be used to characterize and quantify char/charcoal black carbon in environmental media? Org Geochem 39(10):1466-1478. https:// doi.org/10.1016/j.orggeochem.2008.04.026

Mason IL, and Mason IL (1984) Evolution of domesticated animals, Longman London; New York

McGovern PE, Hall GR (2016) Charting a future course for organic residue analysis in archaeology. J Archaeol Method Theory 23(2): 592-622. https://doi.org/10.1007/s10816-015-9253-Z

Monserrat VJ (2013) Sobre los artrópodos en la alfarería y la cerámica popular de la Península Ibérica. Boletín de la Sociedad Entomológica Aragonesa 53:413-441

Morais R (2006) Potes meleiros e colmeias em cerâmica: uma tradição milenar. Saguntum 38:141-161

Morais R (2011) A rota atlântica do mel bético e os contextos da autarcia: vasa mellaria e colmeias em cerâmica: in La cerámica en Galicia: de los Castros a Sargadelos, Actas del XIV Congreso Anual de la Asociación de Ceramología, A Coruña (Spain), pp 75-90

Morais R (2014) News about a Greek vase used to transport and conserve honey: in Miradas sobre la Antiguedad. Homenaje a Ricardo Olmos, Madrid, pp 256-258

Needham S, Evans J (1987) Honey and dripping: Neolithic food residues from Runnymede Bridge. Oxf J Archaeol 6(1):21-28. https://doi. org/10.1111/j.1468-0092.1987.tb00138.x

Nozal MJ, Bernal JL, Gómez LA, Higes M, Meana A (2003) Determination of oxalic acid and other organic acids in honey and in some anatomic structures of bees. Apidologie 34(2):181-188. https://doi.org/10.1051/apido:2003001

Oliveira C, Araújo A, Kuzniarska-Biernacka I, Morais R, Parpot P, Neves I, and Fonseca A (2014) Análise química cromatográfica a fragmentos cerâmicos de potes meleiros e colmeias: in As produções cerâmicas de imitação na Hispania, pp 599-610

Oliveira C, Bettencourt AMS, Araújo A, Gonçalves L, KuźniarskaBiernacka I, Costa AL (2017) Integrated analytical techniques for the study of colouring materials from two megalithic barrows. Archaeometry 59(6):1065-1081. https://doi.org/10.1111/arcm. 12298

Palmer LR (1955) Observations on the linear 'B' tablets from mycenae. Bull Inst Class Stud 2(1):36-45

Peña JT (2007) Roman pottery in the archaeological record. Cambridge University Press, Cambridge. https://doi.org/10.1017/ CBO9780511499685

Pereira AP (2008) Caracterização de mel com vista à produção de hidromel (MSc thesis): MSc thesis, Instituto Politécnico de Bragança, Bragança

Persano P (2016) Honey pots in Etruria. Archaeological and ethnographical comparisons for the stamnoid jars 'a colletto'. Arch Esp Arqueol 89:9-24. https://doi.org/10.3989/aespa.089.016.001

Quixal Santos D, and Jardón Giner P (2016) El registro material del colmenar ibérico de la Fonteta Ràquia (Riba-Roja, València). Lvcentvm 35:43-63

Rageot M, Pêche-Quilichini K, Py V, Filippi JJ, Fernandez X, Regert M (2016) Exploitation of beehive products, plant exudates and tars in Corsica during the early Iron Age. Archaeometry 58(2):315-332. https://doi.org/10.1111/arcm.12172

Regert M, Colinart S, Degrand L, Decavallas O (2001) Chemical alteration and use of beeswax through time: accelerated ageing tests and analysis of archaeological samples from various environmental contexts. Archaeometry 43(4):549-569. https://doi.org/10.1111/14754754.00036

Regert M, Vacher S, Moulherat C, Decavallas O (2003) Adhesive production and pottery function during the Iron Age at the Site of Grand Aunay (Sarthe, France). Archaeometry 45(1):101-120. https://doi. org/10.1111/1475-4754.00098

Roffet-Salque M, Regert M, Evershed RP, Outram AK, Cramp LJE, Decavallas O, Dunne J, Gerbault P, Mileto S, Mirabaud S, Pääkkönen M, Smyth J, Šoberl L, Whelton HL, Alday-Ruiz A, Asplund H, Bartkowiak M, Bayer-Niemeier E, Belhouchet L, 
Bernardini F, Budja M, Cooney G, Cubas M, Danaher EM, Diniz M, Domboróczki L, Fabbri C, González-Urquijo JE, Guilaine J, Hachi S, Hartwell BN, Hofmann D, Hohle I, Ibáñez JJ, Karul N, Kherbouche F, Kiely J, Kotsakis K, Lueth F, Mallory JP, Manen C, Marciniak A, Maurice-Chabard B, Mc Gonigle MA, Mulazzani S, Özdoğan M, Perić OS, Perić SR, Petrasch J, Pétrequin A-M, Pétrequin P, Poensgen U, Joshua Pollard C, Poplin F, Radi G, Stadler P, Stäuble H, Tasić N, Urem-Kotsou D, Vuković JB, Walsh F, Whittle A, Wolfram S, Zapata-Peña L, Zoughlami J (2015) Widespread exploitation of the honeybee by early Neolithic farmers. Nature 527(7577):226-230. https://doi.org/10.1038/nature15757

Ruiz-Matute AI, Hernández-Hernández O, Rodríguez-Sánchez S, Sanz ML, Martínez-Castro I (2011) Derivatization of carbohydrates for GC and GC-MS analyses. J Chromatogr B 879(17-18):1226-1240. https://doi.org/10.1016/j.jchromb.2010.11.013

Sanz ML, Sanz J, Martínez-Castro I (2004) Gas chromatographic-mass spectrometric method for the qualitative and quantitative determination of disaccharides and trisaccharides in honey. J Chromatogr A 1059(1-2):143-148. https://doi.org/10.1016/j.chroma.2004.09.095

Senila L, Gog A, Senila M, Roman C, Silaghi-Dumitrescu L (2012) Development of a GC-MS method for 5-hydroxymethylfurfural determination in wood after steam-explosion pretreatment. Rev Chim 63(6):559-563

Simoneit BRT (2002) Biomass burning — a review of organic tracers for smoke from incomplete combustion. Appl Geochem 17(3):129 162. https://doi.org/10.1016/S0883-2927(01)00061-0

Simoneit BRT, Schauer JJ, Nolte CG, Oros DR, Elias VO, Fraser MP, Rogge WF, Cass GR (1999) Levoglucosan, a tracer for cellulose in biomass burning and atmospheric particles. Atmos Environ 33(2): 173-182. https://doi.org/10.1016/S1352-2310(98)00145-9

Suarez-Luque S, Mato I, Huidobro JF, Simal-Lozano J, Sancho MT (2002) Rapid determination of minority organic acids in honey by high-performance liquid chromatography. J Chromatogr A 955(2): 207-214. https://doi.org/10.1016/S0021-9673(02)00248-0

Svoboda JA, Herbert EW Jr, Thompson MJ, Feldlaufer MF (1986) Selective sterol transfer in the honey bee: its significance and relationship to other hymenoptera. Lipids 21(1):97-101. https://doi.org/ 10.1007/BF02534310

Tamanna N, Mahmood N (2015) Food processing and Maillard reaction products: effect on human health and nutrition. Int J Food Sci 2015(526762):1-6. https://doi.org/10.1155/2015/526762

Teixidó E, Santos FJ, Puignou L, Galceran MT (2006) Analysis of 5hydroxymethylfurfural in foods by gas chromatography-mass spectrometry. J Chromatogr A 1135(1):85-90. https://doi.org/10.1016/j. chroma.2006.09.023

Teodor E, Badea G, Alecu A, Calu L, Radu G (2014) Interdisciplinary study on pottery experimentally impregnated with wine. Chem Pap 68(8):1022-1029. https://doi.org/10.2478/s11696-014-0559-1

Tulloch AP (1971) Beeswax: structure of the esters and their component hydroxy acids and diols. Chem Phys Lipids 6(3):235-265. https:// doi.org/10.1016/0009-3084(71)90063-6

Vanderplanck M, Michez D, Vancraenenbroeck S, Lognay G (2011) Micro-quantitative method for analysis of sterol levels in honeybees and their pollen loads. Anal Lett 44(10):1807-1820. https://doi.org/ 10.1080/00032719.2010.526271

von der Ohe W, Dustmann JH, von der Ohe K (1991) Prolin als Kriterium der Reife des Honigs. Deutsche Lebensmittel-Rundschau 87(12): 383-386

Weilhartner J (2012) Religious offerings in the Linear B tablets: an attempt at their classification and some thoughts about their possible purpose. Faventia (supplementa1):0207-231

Zappalà M, Fallico B, Arena E, Verzera A (2005) Methods for the determination of HMF in honey: a comparison. Food Control 16(3):273277. https://doi.org/10.1016/j.foodcont.2004.03.006 